University of Massachusetts Amherst

ScholarWorks@UMass Amherst

Masters Theses 1911 - February 2014

1974

The influence of phenylthiourea on encapsulation, melanization and survival in larvae of the mosquito, Aedes aegypti, parasitized by the nematode, Neoaplectana carpocapsae.

Michael A. Beresky

University of Massachusetts Amherst

Follow this and additional works at: https://scholarworks.umass.edu/theses

Beresky, Michael A., "The influence of phenylthiourea on encapsulation, melanization and survival in larvae of the mosquito, Aedes aegypti, parasitized by the nematode, Neoaplectana carpocapsae." (1974). Masters Theses 1911 - February 2014. 3027.

Retrieved from https://scholarworks.umass.edu/theses/3027

This thesis is brought to you for free and open access by ScholarWorks@UMass Amherst. It has been accepted for inclusion in Masters Theses 1911 - February 2014 by an authorized administrator of ScholarWorks@UMass Amherst. For more information, please contact scholarworks@library.umass.edu. 
THE INFLUENCE OF PHENYLTHIOUREA ON ENCAPSULATION, NELANIZATION AND SURVIVAL IN IARVAE OF THE MOSQUITO, AEDES AEGYPTI, PARASITIZED BY THE NEMATODE, NEOAPLECTANA CARPOCAPSAE

A Thesis Presented

By

Michael A. Beresky

Submitted to the Graduate School of the University of Massachusetts in partial fulirilment of the requirements for the degree of MASTER OF SCIENCE December, 1974 Major Subject: Entomology 
THE INFLUENCE OF PHENYLTHIOUREA ON ENCAFSULATION, MELANIZATION AND SURVIVAL IN LARVAE OF THE MCSQUITO, AEDES AEGYPTI, PARASITIZED BY THE NEMATODE， NEOAPLECTANA CARPOCAPSAE

\section{A Thesis Preśented}

By

Michael A. Beresky

Approved as to style and content by:

Amald W. Hale

(Chairman of Committee)
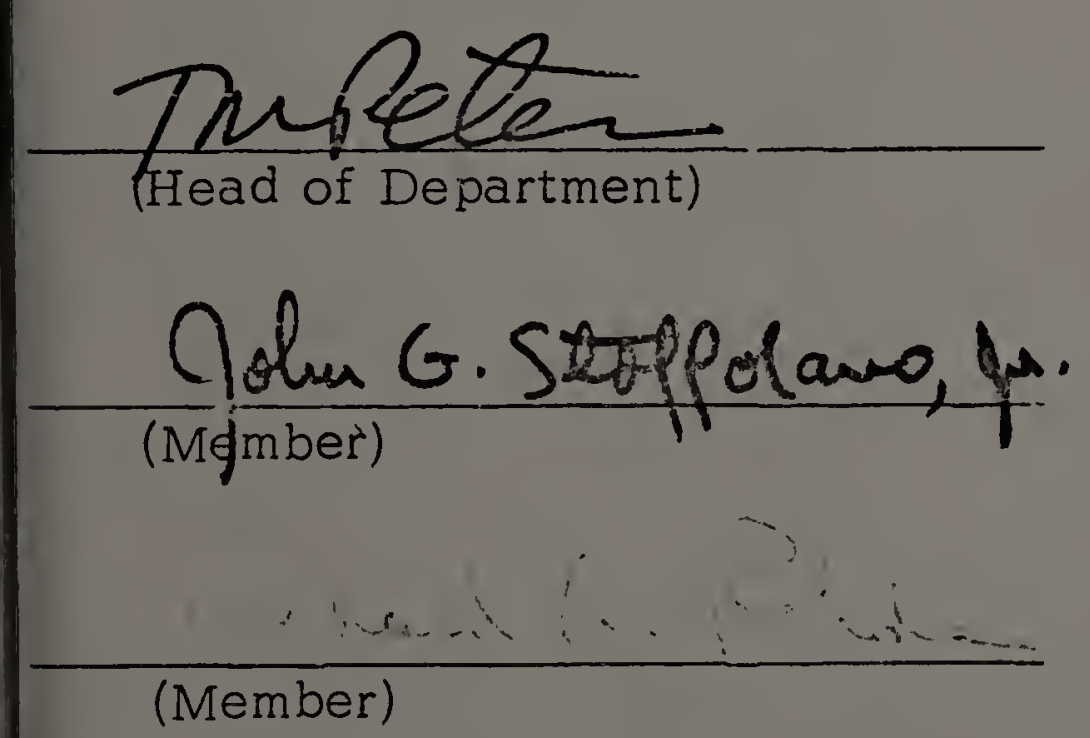

December, 1974 


\section{ACKNOWLEDGMENTS}

I would like to express my appreciation to Dr. D. W. Hall, my advisor, for the guidance and encouragement I received from him throughout this study. I would also like to thank Dr. J. G. Stoffolano for his advice, and Dr. R. A. Rohde for his assistance with nematode problems. I am grateful to Dr. R. A. Damon for his help with the statistical analysis of the data. A special thanks goes to Dr. J. F. Hanson for his help with the writing of this thesis. Finally I would like to thank all the other people who helped me with my education and research. 


\section{EXPLANATORY NOTE}

This thesis is prepared in 2 parts. The 1st part which consists of the Abstract, Introduction, Materials ard Methods, Acknowledgments, and References, is a manuscript which will be submitted for publication. The 2nd part of the thesis (Appendix) will not be published, and contains a complete Literat're Review, Additional Materials and Methods, Additional Results and Discussion, Additional References, anc sections which are pertinent to the entíre thesis. 
MANUSCRIPT FOR PUBLICATION

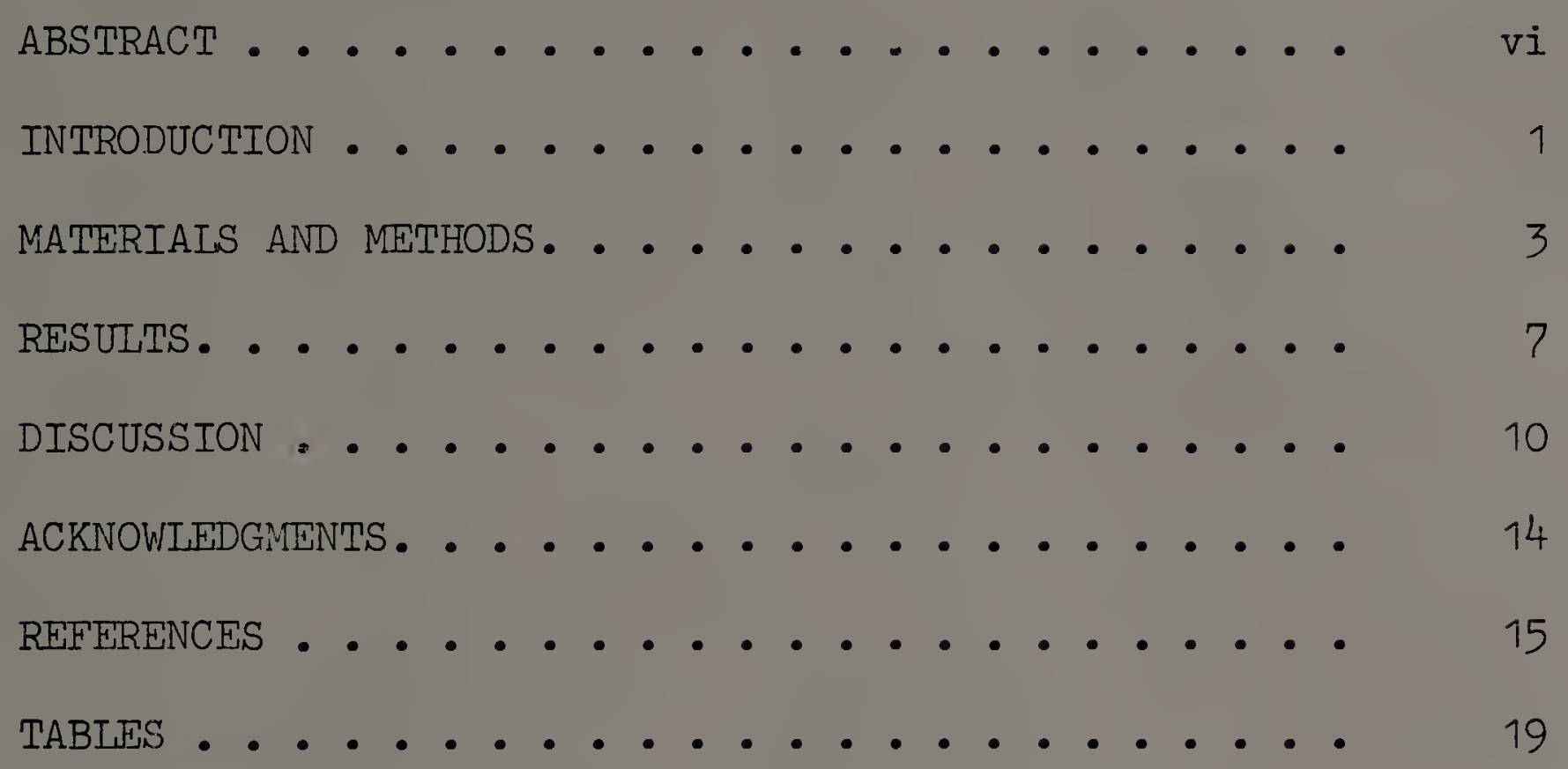

APPENDIX

LITERATURE REVIEW. •. . . . . . . . . . . 22

ADDITIONAI MATERIALS AND MELHODS . . . . . . • 27

ADDITIONAI RESULTS AND DISCUSSION. $\cdot \cdot \cdot \cdot \cdot \cdot \cdot \cdot \cdot 29$

REPORT ON THE CULTIVATION OF AXENIC NEOAPLECTANA

CARPOCAPSAE •. . . . . . . . . . . 48

ADDITIONAL REFERENCES. . . . . . . . . . . 50 


\section{SUMMARY}

Phenylthiourea (PIU) treated and untreated Aedes aegypti larvae were exposed to concentrations of 1000-4000 Neoaplectana carpocapsae juveniles per $\mathrm{ml}$ for $1 \mathrm{hr}$. During the first $9 \mathrm{hr}$ after exposure, the PTU treated larvae had a significantly lower mortality than the untreated larvae. The rate of encapsulation or melanization of $\mathrm{N}$. carpocapsae juveniles within the hemocoeles of the mosquito larvae was investigated by gross dissections and histological techniques. The amount of melanization occurring in the PIU treated larvae was found to be significantly reduced. Possible explanations were given for the observed differences in mortality. One possibility was that PTU may inactivate the phenoloxidase system in mosquito larvae, thereby inibibiting the formation of toxic melanin intermediates. Another possibility is that PTU may inactivate a toxin emitted by the nematode or in some way have an effect on the bacterium, Achromobacter nematophilus. 


\section{INTRODUCT:LON}

Many insect species have been found to form melanic capsules around invading nematodes (Poinar, 1969). This defense reaction occurs in Aedes aegypti larvae when infective stage Neoaplectana carpocapsae (DD-136 strain) enter the insect's hemocoel (Bronskill, 1962; Welch and Bronskill, 196?). Encapsulation begins almost immediately after the nematode penetrates the mosquito's midgut wall, and is usually complete 4 to $5 \mathrm{hr}$ later (Bronskill, 1962).

The phenoloxidase inhibitor, phenylthiourea (PTU), has been used to inhibit melanin formation in insect; capsules (Salt, 1956; Nappi, 1973). The chemical is often injected into the insect (Salt, 1956; Brewer and Vinson, 1971; Nappi, 1973), but, Nappi (1973) was able to inhibit the formation of melanic capsules in Drosophila by adding PTU to the rearing medium.

Welch and Bronskill (1962) reported that 4th instar A. aegypti larvae died 25 to $30 \mathrm{hr}$ after exposure to $\mathrm{N}$. carpocapsae. They also reported that death occurred as a result of septicemia due to a pathogenic bacterium carried by the nematode. The bacterium was isolated by Poinar and Thomas (1965), and given the name Achromobacter

\section{nematophilus.}

Preliminary experiments indicated that when the nematode concentration was between 1000 and 10,000 nematodes per $\mathrm{ml}$ the majority of A. aegypti larvae died within $6 \mathrm{hr}$ after exposure to the nematodes. This early mortality was greatly reduced if the larvae were reared in the presence of PTU prior to exposure to $N$ - carpocapsae. The main ob- 
2.

jectives of the present study were to investigate the effects of PTU on the encapsulation of $\mathrm{N}$. carpocapsae in 4 th instar $\mathrm{A} \cdot$ aegypti larvae, and to assess the possible importance of melanization as the cause of early mortality. 
MATERIALS AND METHODS

Experimental Animals

An Aedes aegypti colony was initiated for experimental purposes using eggs obtained from Dr. T. M. Peters (University of Massachusetts, Department of Entomology), which were part of a culture originally obtained from Rutgers University. The larvae used in all experiments were vacuum hatched at $25 \mathrm{p} . \mathrm{s} . \mathrm{i}$. for $30 \mathrm{~min}$, and reared according to the standard rearing technique of Peters et al. (1969). Larvae were reared at a temperature of approximately $80^{\circ} \mathrm{F}$. , and a photoperiod of $16 \mathrm{hr}$. Fourth instar larvae were obtained on the 4 th day, with pupation occurring on the 6 th day.

Neoaplectana carpocapsae nematodes were obtained from Dr. D. P. Harlan, Bicenvironmental Insect Control Laboratory, Stoneville, Mississippi, and were prcpagated in Galleria me?lonella larvae by the technique of Dutky et al. (1964). Infective stage juveniles were used in all experiments.

\section{Experimental Techniques}

Experiments were conducted to determine the effects of phenylthiourea (PTU) on A. aegypti larvae. The first set of experiments consisted of rearing mosquito larvae in various concentrations of PTU from the time of hatch, until the 5th day. Surviving larvae were then counted and the drJ weights were recorded. Rearing mosquito larvae in PTU solutions in this manner resulted in decreased survival and stunted growth, even at $0.01 \% \mathrm{PTU}$

Another set of experiments was conducted in which larvae were 
reared until the 4 th instar without PTU. On the 4 th day, the larvae were placed in the various concentrations of PTU. On the 5 th day, the surviving larvae were prepared and examined as described above. The results of these experiments indicated that after $24 \mathrm{hr}$ of exposure to $0.01 \%$ PTU, mosquito larvae showed no differences from the control larvae in mortality and weight per larva. This method of rearing, and concentration of PTU was used in all subsequent experiments where PTU treated mosquito Iarvae were used.

The oxygen consumption of 5-day-old, PTU treated mosquito larvae, was compared with that of untreated larvae. Oxygen consumption was measured using the Gilson differential respirometer by the technique of Barbosa (1971). The oxygen consumption of PTU treated larvae was always fourd to be lower than the untreated larvae, which was taken as evidence that the PTU was actually entering mosquito larvae.

The effectiveness of a $0.01 \%$ PTU solution as a melanin inhioitor in tissues of $A$ - aegypti larvae was determined histochemically by the method of Rodriquez and McGavran (1969). Five-day-old mosquito larvae were cut into 4 sections consisting of the thorax, abdominal segments 1-3, abdominal segments 4-6, and the anal segment. The sections were cut in cold $4 \%$ paraformaldehyde fixative in $0.1 \mathrm{M}$ cacodylate buffer (pH 7.4). These sections were incubated for $10 \mathrm{hr}$ in $0.1 \%$ DOPA, either with, or without $0.01 \%$ PTU present. The tissues rere embedded in paraffin, sectioned at $8 \mu$, counterstained with nuclear fast red, and examined microscopically for the presence of melanin.

Inoculation of mosquito larvae with nematodes was conducted the same way in all experiments. Nematodes were examined to insure that 
at least $75 \%$ of them were moving, and then placed in the Trager's salt solution used for rearing mosquitoes. Next, the nematode concentration was determined by the method of Dutky et al. (1964). Preliminary experiments showed that nematode concentrations of 1000 to 10,000 nematodes per $\mathrm{ml}$ produced 50 to $70 \%$ mortality of mosquito larvae within the first $6 \mathrm{hr}$ after exposure. The approximate concentrations of nematodes used were 4000,2000 , and 1000 per $\mathrm{ml}$, unless otherwise stated. The nematodes were placed in $0.01 \%$ PTU solution if they were to be used in conjunction with PTU treated mosquito larvae. Controls without nematodes were also used in all experiments. Ten $\mathrm{ml}$ of the nematode suspensions were placed in sterile, $60 \mathrm{X} 15 \mathrm{~mm}$, plastic petri dishes.

Mosquito larvae were deprived of food for $3 \mathrm{hr}$ prior to initiation of the experiments to insure rapid ingestion of the nematodes. Twentyfive larvae were then placed in each plastic petri dish. The larvae were exposed to nematodes for $1 \mathrm{hr}$, rinsed in distilled water, and returned to the plastic petri dishes with $10 \mathrm{ml}$ of either Trager's salt solution, or $0.01 \%$ PTU in Trager's salt solution, depending upon the treatment they were in. The dishes were examined for mortality of mosquito larvae at $3 \mathrm{hr}$ intervals for $9 \mathrm{hr}$. In all experiments, mortality represented not only the number of dead mosquito larvae, but also the number of moribund larvae. Moribund larvae were incapable of swimming and responding consistently when touched with forceps. Moribund larvae were capable of flexion movements; their mouthparts were usually moving, and their heart was still beating. It was assumed that these larvae would be dead within a short time. 
All dead and moribund mosquito larvae were removed from their respective dishes every $3 \mathrm{hr}$ and dissected. The number of nematodes within their hemocoels were counted and recorded. After $9 \mathrm{hr}$, the same procedure was performed on all surviving mosquito larvae. All nematodes dissected from the hemocoels were classified into 3 groups:

1. Non-encapsulated nematodes which showed no signs of melanin or encapsulation.

2. Partly encapsulated nematodes which had some melanin around them but were still visible through the capsule and were still capable of active serpentine movement.

3. Completely encapsulated nematodes, which were completely enveloped by a uniformly black melanin capsule. These nematodes were incapable of active movement, although some could still move sluggishly.

Experiments were conducted to determine the distribution of nematodes within PTU treated and untreated mosquito larvae. These experiments were similar to the previous experiments, however, the number of nematodes within each mosquito's head, thorax and abdomen were recorded. The nematode suspensions used in these experiments contained 3000 nematodes per $\mathrm{ml}$

Histological sections were prepared to determine the effects of PTU on encapsulation of nematodes by mosquito larvae. Five living and 5 dead mosquito larvae from both PTU and control treatments were placed in Carnoy's fixative every hour for $3 \mathrm{hr}$ after exposure to nematodes. The mosquito larvae were embedded in paraffin, sectioned at $8 \mu$ and stained with Delafield's hematoxylin with eosin Y counterstain. 
RESULTS

Histochemical tests indicated that $0.01 \%$ PTU was capable of inhibiting melanin formation in vitro in various tissues of Aedes aegypti larvae. Untreated tissues showed darkened cuticles, tracheae, and areas of the fat body, when incubated in DOPA for $10 \mathrm{hr}$. When $0.01 \%$ PTU was present, only a slight degree of darkening of the cuticle was evident. It should be pointed out that in phenoloxidase positive hemocytes of $\underline{A}$. aegypti's anal papillae, melanin formation was not inhibited by $0.01 \%$ PTU, but was inhibited by $0.1 \%$ PTU (Andreadis, 1974).

The mortality of PTU treated and untreated 4 th instar $\underline{A}$. aegypti larvae, which were exposed to various concentrations of $\mathrm{N}$ - carpocapsae infective stage juveniles, is shown in Table 1. PTU treated mosquito larvae had a much lower per cent mortality tinan untreated larvae. This difference was found to be highly significant $(P>0.01)$. These data indicate that $0.01 \%$ PTU may in some way protect mosquito larvae from the initial effects of $N$. carpocapsae parasitism.

The number of nematodes dissected from the hemocoels of mosquito larvae in these experiments is shown in Table 2. The data indicate that differences in mortality between PTU treated and untreated larvae are not due to differences in the numbers of nematodes parasitizing the larvae. PTU treated larvae had a significantly higher $(B>0.01)$ number of nematodes per larva than untreated larvae.

It can be seen that the number of nematodes in living larvae is usually lower than the number in dead larvae (Table 2). However, in some groups of live mosquito larvae, there were more nematodes per 
larva than in some groups of dead mosquito larvae. Thus, mortality does not appear to be solely a function of the number of nematodes parasitizing mosquito larvae.

The results of categorizing the nematodes dissected from the hemocoels of mosquito larvae, are summarized in Table 3. The per cent encapsulation represents the percentage of nematodes which were either partly or completely encapsulated. These data show a highly significant difference $(P>0.01)$ between PTU treated and untreated mosquito larvae in the per cent encapsulation of the nematodes. Untreated larvae initiated encapsulation on most nematodes entering their hemocoels within the first $3 \mathrm{hr}$ period, and all nematodes found in the hemocoels after $3 \mathrm{hr}$ were at least partly encapsulated. By $9 \mathrm{hr}$ nearly all nematodes in the hemocoels of both dead and living untreated larvae were completely encapsulated. In PTU treated larvae, most nematodes were not even partially encapsulated within the first $3 \mathrm{hr}$, and no nematodes were found to be completely encapsulated during this time period. By 6 hr most nematodes were partially encapsulated, and after $9 \mathrm{hr}$ nearly all nematodes found within living and dead PTU treated mosquito larvae were completely encapsulated.

These results indicate that $0.01 \%$ PTU does not completely inhibit the encapsulation (or melanization) process in $\underline{A}$ aegypti larvae. However, there is about a $3 \mathrm{hr}$ delay in the encapsulation of nematodes by PTU treated larvae. The encapsulation values obtained for the 6 and $9 \mathrm{hr}$ groups of PTU treated larvae correspond rather closely with the values obtained for the 3 and $6 \mathrm{hr}$ groups of untreated larvae. Therefore, it appears that in PTU treated larvae, after an initial 
delay, encapsulation proceeds at a comparable pace to that found in untreated larvae.

Bronskill (1962) described encapsulation of $\underline{N}$. carpocapsae in $\underline{A}$. aegypti larvae as a two step process. First, a thin melanized sheath was formed around the nematode, and then melanin particles were added. A two step encapsulation process was also described in Culex pipiens larvae by Poinar and Leutenegger (1971). They found that a homogeneous matrix was first deposited around $\underline{N}$ carpocapsae juveniles, and this matrix later melanized.

Since in the present study, PTU caused a delay in encapsulation, it was thought that a histological investigation might show if this delay occurred after the 1st step in encapsulation had been initiated. The histological study showed that encapsulation in PTU treated larvae progressed in the same way as in untreated larvas, but was somewhat delayed in initiation. Within a treatment (PTU and untreated larvae), the capsules were similar in appearance in both the living and the dead larvae.

The experiment conducted to determine the relative migration of nematodes in both PTU treated and untreated mosquito larvae showed little difference between the treatments. There were only slightly fewer nematodes per larva in the heads of living larvae (0.61 vs 0.56). Thus, it appears that the actual migration of nematodes within parasitized mosquito larvae is probably not a determining factor in mortality during the first $9 \mathrm{hr}$. It also appears that $0.01 \%$ PTU has no noticeable effect on the $\underline{N}$. carpocapsae juveniles and their ability to parasitize and migrate through $\underline{A}$. aegypti larvae. 


\section{DISCUSSION}

There may be many factors causing the early death of Aedes aegypti larvae parasitized by Neoaplectana carpocapsae, and many possibilities as to why PTU alters the phenomenon. Some of the possibilities have been investigated while others remain as speculation only.

There is a possibility that PTU may in some way affect the pathogenicity of Achromobacter nematophilus. Lysenko (1963) found that the

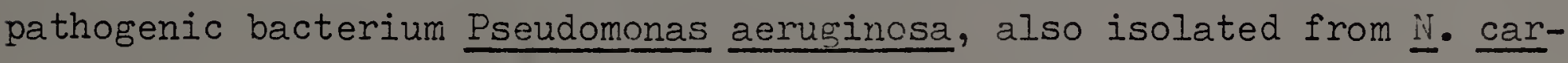
pocapsae, produced a protein which was toxic when injected into Galleria larvae. This toxin was thought to attack the phenoloxidase system of the insects. When the protein was injected along with PTU it was no longer toxic. A phenomenon such as this may occur with A. nematophilus and PTU treated A. aegypti larvae, but as of yet there is no evidence of a toxin from $\underline{A}$. nematophilus.

PTU may affect N. carpocapsae in some way to make them less damaging to mosquito larvae. The possibility that PTU causes slower penetration and movement of the nematodes was investigated and is not worthy of much consideration. As seen in Table 2 , the survival of more PTU treated larvae was not due to having fewer nematodes in their hemocoels than the untreated larvae. In almost every case there were more nematodes in the PTU treated larvae than in the untreated larvae.

N. carpocapsae may kill mosquito larvae by releasing a toxin within the insects. Poinar and Thomas (1966) suggested that a toxin might be produced by $\underline{N}$. carpocapsae which is capable of killing Galleria larvae. However, there is actually no evidence for the existence of such a toxin. 
The actual physical damage to mosquito larvae from having nematodes in their hemocoels may be a major cause of mortality. This physical damage is related to the movement of the nematodes within mosquito hemocoels. There was no difference between the migration of nematodes in the PTU treated and untreated larvae. Therefore, there probably was little difference between the two groups in the amount of damage to the larvae.

PTU may somehow counteract the effects of injury to mosquito larvae and it is on this topic that some interesting relationships can be drawn between PTU and mortality.

Biochemical reactions associated with melanin formation occur in certain pathophysiological disorders of insects, such as wound healing; (Lai-Fook, 1966; Preston and Taylor, 1970; Nappi, 1974). Lai-Fook (1966) considered melanin formation to be one of the first phases in wound repair in insects. Sussman (1949) suggested that in Hyalophora cecropia, melanin formation after injury functioned to remove toxic substances (phenols) from the hemolymph. He thought that the toxic substances were liberated from injured tissues and could circulate in the hemolymph and poison the insects. Cottrell (1964) hypothesized that when insect tissues are damaged, tyrosinases and suitable substrates are released, and these materials may react to form melanin. Melanin intermediates (specifically quinones) were said to be incompatible with life and capable of killing insect parasitoids (Taylor, 1969). Thus, if quinones formed during melanin formation (linked with encapsulation and injury) were actually the toxic materials hypothesized by Sussman (1949), then an inhibition of phenoloxidases by PTU 
would not allow these toxic substances to form. This might explain why a greater number of PTU treated mosquito larvae survived. Unfortunately, there is no data available on whether or not these quinones are found in the hemolymph of injured insects, or the amounts needed to cause death.

Recent work by zlotkin et al. (1973) demonstrated that phenoIoxidases from tenebrionid hemolymph were toxic and caused death when injected into Sarcophaga and Calliphora larvae. The actual cause of death was not known but shortly before death, which occurred from 1 to $4 \mathrm{hr}$ after the injections, the hemolymph of the injacted animals melanized. It was also discovered that death could be prevented by the addition of PIU to the injected hemolymph. These findings correlate with the findings of the present study using A. aegypti larvae. The phenoloxidase system of the mosquito larvae is probably activated by the nematodes, bacteria, injury, and encapsulation occurring within the larvae. Some of these agents are known to activate the system in some closely related insects (Poinar and Leutenegger, 1971; Gotz and Vey, 1974). It is possible that the activation of the phenoloxidase system may cause an accumulation of toxic substances which may be linked with the cause of the early death of the larvae. The decreased mortality observed in PTU treated larvae may be explained by PTU inhibiting the phenoloxidase system and melanin formation. This inhikition may serve to block the formation of toxic melanin intermediates, and thus, these mosquito Iarvae Iive Ionger than the untreated larvae.

In certain instances the immune system of vertebrates is known to 
13.

be harmful to the host. If the phenoloxidase system can cause the death of mosquito larvae, it would be the first instance known in arthropod immunity where the immune system can be deleterious to the host. 
14.

\section{ACKNOWLEDGMENTS}

The authors are greatiy indebted to Dr. J. G. Stoffolano Jr. and Dr. R. A. Rohde for their advice and assistance in preparing this paper. Special thanks go to Dr. R. A. Damon Jr. for his help with the statistical analysis of the data. 
15.

\section{REFERENCES}

Andreadis, T. G. 1974. Personal communication.

Barbosa, P. 1971. Some effects of overcrowding on the respiration of larval Aedes aegypti. Ph.D. Thesis, University of Massachusetts. Brewer, F. D., and Vinson, S. B. 1971. Chemicals affecting the encapsulation of foreigm material in an insect. J. Invertebr. Pathol., $18,287-289$

Bronskill, J.F. 1962. Encaposulation of rhabditid nematodes in mosquitoes. Can. J. Zool., 40, 1269-1275.

Cottrell, C. B. 1964. Insect ecdysis with particular emphasis on cuticular hardening and darkening. Adv. Insect Physiol., 2, 175-218.

Dutky, S. R., Thompson, J. V., and Cantwell, G. E. 1964. A technique for the mass rearing of the DD-136 nematode. J. Insect Pathol., $6,417-422$

Gotz, P., and Vey, A. 1974. Humoral encapsulation in Diptera (Insecta): defence reactions of Chironomus larvae against fungi. Parasitology, $68,193-205$

Lai-Fook, J. 1966. The repair of wounds in the integument of insects. J. Insect Physiol., 12, 195-226.

Lysenko, 0. 1963. The mechanisms of pathogenicity of Pseudomonas aeruginosa (Schroeter) Migula. I. The pathogenicity of strain N-06 for larvae of the greater wax moth Galleria mellonella (Linnaeus). J. Insect Pathol., 5, 78-82. 
Lysenko, 0. 1963. The mechanisms of pathogenicity of Pseudomonas aeruginosa (Schroeter) Migula. II. A toxic substance produced in filtrates of cultures. J. Insect Pathol., 5, 83-88.

Lysenko, 0. 1963. The mechanisms of pathogenicity of Pseudomonas aeruginosa (Schroeter) Migula. III. The effect of N-06 toxin on the oxygen consumption of Galleria prepupae. J. Insect Pathol., 5, 89-93.

Lysenko, 0. 1963. The mechanisms of pathogenicity of Pseudomonas aeruginosa (Schroeter) Migula. IV. The antigenic character of the toxin produced by strain N-C6. J. Insect Pathol., 5, 94-97. Nappi, A. J. 1973. The role of melanization in the immune reaction of larvae of Drusophila algonquin against Pseudeucoila bochei. Parasitology, 66, 23-32.

Nappi, A. J. 1974. Parasite encapsulation in insects. 48 pp. (K. Maramorosch, ed.) Academic Press, New York (In Press). Peters, T. M., Chevone, B. I., Greenough, N. C., Callahan, R. A., and Barbosa, P. 1969. Intraspecific competition in Aedes aegypti (I.) larvae: I. Equipment, techniques and methodology. Mosq. News, $29,667-674$,

Poinar, G. O., Jr. 1969. Anthropod immunity to worms. In: "Immunity to Parasitic Animals" (Jackson, Herman, and Singer, eds.), pp. 173-210. Appleton-Century-Crofts, New York. Poinar, G. O., Jr., and Leutenegger, R. 1971. Ultrastructural investigation of the meianization process in Culex pipiens (Culicidae) in response to a nematode. J. Ultrastruct. Res., 36, $149-158$ 
Foinar, G. O., Jr., and Thomas, G. M. 1965. A new bacterium, Achromobacter nematophilus sp. nov. (Achromobacteriaceae:

Eubacteriales) associated with a nematode. Int. Bull. Bacteriol. Nomen. Texon., 15, 249-252.

Poinar, G. O., Jr., and Thomas, G. M. 1966. Significance of Achromobacter nematophilus Poinar and Thomas (Achromobacteriaceae: Eubacteriales) in the development; of the nematode, DD-136 (Neoaplectana sp. Steinernematidiae). Parasitology, 56, 385-390. Preston, J. W., and Taylor, R. I. 1570. Observations on the phenoloxidase system in the haemolympr. of the cockroach Leucophaea maderae. J. Insect Physiol., 16, 1729-1744.

Rodriquez, H. A., and McGavran, M. H. 1969. A modified DOPA reaction for the diagnosis ana investigation of pigment cells. Am. J. Clin. Pathol., 52, 219-227.

Salt, G. 1956. Experimental studies ir insect parasitism. IX. The reactions of a stick insect to an alien parasite. Proc. Roy. Soc. Lond., B, 146, 93-108.

Sussman, A. S. 1949. The functions of tyrosinase in insects. Quart. Rev. Biol., $24,328-338$.

Taylor, R. I. 1969. A suggested role for the polyphenol-phenoloxidase system in invertebrate immunity. J. Invertebr. Pathol., $14,427-428$

Welch, H. E., and Bronskill, J.F. 1962. Parasitism of mosquito larvae by the nematode, DD-136 (Nematoda: Neoaplectanidae). Can. J. Zool., 40, 1263-1268. 
18.

Zlotkin, E., Gurevitz, M., and Shulov, A. 1973. The toxic effects of phenoloxidase from the haemolymph of tenebrionid beetles. J. Insect Physiol., 19, 1057-1065. 
TABLE 1

Per Cent Mortality of PTU Treated and Untreated 5-Day-Old Aedes aegypti Larvae Exposed to Various Concentrations of Neoaplectana carpocapsae for 1 Hour $^{a}$

\begin{tabular}{ccccccc} 
& \multicolumn{3}{c}{ PTU Treated } & \multicolumn{3}{c}{ Untreated } \\
\cline { 2 - 7 } $\begin{array}{c}\text { Hours } \\
\text { After } \\
\text { Exposure }\end{array}$ & \multicolumn{2}{c}{ Nematodes per mI } & \multicolumn{2}{c}{ Nematodes per ml } \\
\cline { 2 - 7 } & 4000 & 2000 & 1000 & 4000 & 2000 & 1000 \\
\hline 3 & 20.0 & 17.3 & 17.3 & 34.7 & 25.3 & 30.7 \\
6 & 32.0 & 29.3 & 32.0 & 49.3 & 44.0 & 44.0 \\
9 & 45.3 & 44.0 & 49.3 & 69.3 & 66.7 & 60.0 \\
\hline
\end{tabular}

Data combined from 3 experiments 


\section{TABLE 2}

Mean Nematodes Per Aedes aegypti Larva Exposed to Neoplectana carpocapsae for 1 Hour $^{a}$

\begin{tabular}{ccccccc}
\hline & \multicolumn{3}{c}{ PTU Treated } & \multicolumn{3}{c}{ Untreated } \\
\cline { 2 - 7 } $\begin{array}{c}\text { Hours } \\
\text { After } \\
\text { Exposure }\end{array}$ & \multicolumn{3}{c}{ Nematodes per m 1} & \multicolumn{2}{c}{ Nematodes per m. } \\
\cline { 2 - 7 } & 4000 & 2000 & 1000 & 4000 & 2000 & 1000 \\
\hline 3 & 11.60 & 11.23 & 10.46 & 7.96 & 9.26 & 6.09 \\
6 & 10.33 & 8.11 & 7.45 & 8.55 & 10.07 & 7.70 \\
$9^{b}$ & 11.00 & 8.08 & 6.29 & 6.47 & 7.29 & 5.08 \\
$9^{c}$ & 5.30 & 4.54 & 3.95 & 5.00 & 5.64 & 4.27 \\
\hline
\end{tabular}

Data combined from 3 experiments

Dead Iarvae

${ }^{c}$ Surviving larvae 


\section{TABLE 3}

Per Cent Encapsulation of Neoaplectana carpocapsae by PTU Treated and Untreated 5-Day-Old Aedes aegypti Larvae Exposed to Nematodes for 1 Hour $^{a}$

\begin{tabular}{|c|c|c|c|c|c|c|c|c|}
\hline & & & \multicolumn{3}{|c|}{ PTU Treateả } & \multicolumn{3}{|c|}{ Untreated } \\
\hline \multirow{2}{*}{\multicolumn{3}{|c|}{$\begin{array}{l}\text { Hours } \\
\text { After } \\
\text { Exposire }\end{array}$}} & \multicolumn{3}{|c|}{ Nematodes per $\mathrm{ml}$} & \multicolumn{3}{|c|}{ Nematodes per ml } \\
\hline & & & 4000 & 2000 & 1000 & 4000 & 2000 & 1000 \\
\hline \multirow[t]{2}{*}{3} & $\% 1$ & Encapsulation & 40.80 & 39.04 & 66.18 & 96.62 & 90.34 & 74.29 \\
\hline & $\%$ & Complete Capsules & 0 & 0 & 0 & $12 \cdot 50$ & 11.32 & 26.92 \\
\hline \multirow[t]{2}{*}{6} & $\%$ & Encapsulation & 89.25 & 76.71 & 93.90 & 100 & 100 & 100 \\
\hline & $\%$ & Complete Capsules & 24.10 & 12.50 & 27.27 & 59.57 & 58.16 & 63.64 \\
\hline \multirow[t]{2}{*}{$9^{b}$} & $\%$ & Encapsulation & 98.35 & 100 & 100 & 100 & 100 & 100 \\
\hline & & Complete Capsules & 64.71 & 71.13 & $65 \cdot 91$ & 90.72 & 96.77 & 81.97 \\
\hline \multirow[t]{2}{*}{$9^{c}$} & $\%$ & Encapsulation & 100 & 100 & 100 & 100 & 100 & 100 \\
\hline & & Complete Capsules & 97.64 & 94.64 & 92.47 & 99.13 & 98.53 & 100 \\
\hline
\end{tabular}

a Data combined from 3 experiments

$b_{\text {Dead Iarvae }}$

${ }^{\mathrm{c}}$ Surviving larvae 


\section{LITERATURE FEVIEW}

Nematodes were found parasitizing larvae of the codling moth (Laspeyresia pomonella) in Virginia, and placed in the genus Neoaplectana (Dutky and Hough, 1955). Concurrently, Weiser (1955) described a new nematode species, Neoaplectana carpocapsae, which was found in codling moth larvae in Czechoslovakia. The nematode found in America remained unnamed for many years and was often referred to by its U.S.D.A. accession number, $D D=136$ (Dutky et al., 1964). Over the yeari, a great deal of confusion developed over whether or not the two nematodes were indeed the same species, Neoaplectana carpocapsae Weiser, and they decidea to call the nematode discovered by Dutky and Hough (1955) the DD-136 strain (Niklas, 1967; Poinar, 1967; Poinar et a.l, 1972).

N. carpocapsae is capable of parasitizing a wide variety of insects, some of which are listed by Poinar (1971). Aedes aegypti larvae were found to be susceptible to experimental parasitization by $\mathbb{N}$. carpocapsae (Bronskill, 1962; Welch and Bronskill, 1962). The nematodes are ingested by the mosquito larvae and enter the insect's hemocoel through the midgut wall (Welch and Bronskill, 1962). Shortly after entering the hemocoel, the nematodes release a pathogenic bacterium, which kills mosquito larvae (Welch and Bronskill, 1962). The bacterium in $\underline{N}$. carpocapsae was later isolated by Poinar and Thomas (1965) and named Achromobacter nematophilus.

Aedes aegypti and some other species of mosquito larvae have been found to react to nematode parasitization by using a process known as 
encapsulation (Bronskill, 1962; Welch and Bronskill, 1962; Poinar and Leutenegger, 1971). The subject of encapsulation and insect defense mechanisms has been extensively discussied in reviews by Salt ( 1963 , 1970), and more recently by Whitcomb et al. (1974).

According to Salt (1970), encapsulation is carried out exclusively by hemocytes, and melanization linked with encapsulation follows the cellular reactions. Ir opposition to Salt (1970), are the findings of certain researchers who have described the processes of encapsulation and melanization in culicids, and who believe that these processes may be humoral and carried out without the direct association of the insect's hemocytes (Bronskill, 1962; Esslinger, 1962; Poinar and Leutenegger, 1971).

A precise description of the process of capsule formation around $N$. carposapsae in A. aegypti larvae was provided by Bronskill (1962). The formation of the capsules was described as a two step process. First, melanized sheaths, that did not appear to be directly derived from hemocytes, were formed. Then, hemocytes were added directly to the capsules in the form of particles of melanin. Since the hemocytes were not deposited in a recugnizable cellular form, the finished capsules appeared to be acellular.

The encapsulation of $\underline{N}$. carpocapsae by Culex pipiens larvae was described by Poinar and Leutenegger (1971). I'sing electron micrographs, they found that an initial homogeneous matrix without any definite structure or cellular organelles was precipitated directly from the hemolymph. This initial matrix appears to be similar to the melanized sheaths found in A. aegypti by Bronskill (1962). However, unlike Bron- 
skill (1962), Poinar and Leutenegger (1971) were unable to find evidence of any cellular participation in the remainder of the encapsulation process by $\underline{C}$. pipiens larvae, and called the process humoral encapsulation.

In many insects, encapsulation is associated with the production of a dark pigment, which has often been called melanin (Salt, 1963; Stoffolano and Streams, 1971). Evider.ce has gradually accumulated showing that this daik pigment in various insect capsules is indeed melanin in the chemical sense (Salt, 1956; Poinar et al., 1968; Gotz, 1969; Poinar and Leutenegger, 1971; Nappi, 1973; Babu and Hall, 1974; Gotz and Vey, 1974). Poinar and Leutenegger (1971) performed a set of chemical tests on the humoral capsules of Culex pipiens larvae and found that the results agreed with the diagnostic tests for melanin given by Fox (1953). Therefore, the authors assumed that the pigment in the capsule of $\underline{\mathrm{C}}$. pipiens larvae was melanin.

The enzymes responsible for the formation of melanin in insects are called tyrosinases, phenoloxidases, or polyphenoloxidases (Dennell, 1949; Chadwick, 1956; Preston and Taylor, 1970; Pye and Yendol, 1972). They may be present in the hemolymph of some insects (Zilotkin et al., 1973), or localized in the hemocytes of others (Rizki and Rizki, 1959; Pye and Yendol, 1972). They contain copper (Lerner and Fitzpatrick, 1950) and at leást some are known to occur as proenzymes which are activated to initiate melanin production (Dennell, 1949; Ohnishi, 1959; Evans, 1967; Ashida and Ohnishi, 1967). The enzymes involved in melanin formation can be inactivated by chemicals, such as phenylthiourea (PIU), which chelat,es copper, and 
thus melanin formation is inhibited or blocked (Lerner and Fitzpatrick, 1950). Certain researchers have used FTU to block melanin formation in the encapsulation process of insects (Salt, 1956; Nappi, 1973). Salt (1956) injected crystals of PTU into the stick insect, Carausius, whicn prevented melanin formation in capsules, and Nappi (1973) blocked melanization and capsule formation in Drosophila larvae by adding PTU to the rearing medium.

The effects of PTU on humoral caysules, which have only been found to occur in culicids and a few other insects (Welch and Bronskill, 1962; Gotz, 1969; Poinar and Leutenegger, 1971), has not been determined. However, Gotz and Vey (1974) injected glutathione, also an inhibitor of phenoloxidases (Lerner and Fitzpatrick, 1950; Brewer and Vinson, 1971), into Chironomus larvae to inhibit melanin formation in humoral capsules. Gotz and Vey (1974) also discovered that the encapsulation process was completely inhibited and they considered encapsulation and melanin formation to be the same process in this Chironomus defense mechanism.

The functions and importance of melanin formation in insect defense mechanisms are nut fully known (Salt, 1970; Nappi, 1974). The effects of melanization and melanin intermediates as humoral bactericides are discussed by Whitcomb et al. (1974). Many authors have found that melanization ?.inked with cellular (Miller, 1943; Schell, 1952; Muldrew, 1953; Salt, 1955, 1956, 1957; Misko, 1972) and humoral (Welch and Bronskill, 1962; Gotz, 1969; Poinar and Leutenegger, 1971; Gotz and Vey, 1974) encapsulation may aid in the defense against, and may even kill certain metazoan parasites. Sussman (1949) suggested that melanin 
formation in response to injury in Hyalophora cecropia, was a mechanism for the removal of toxic substances, such as phenols, which arise from the injury to various tissues. He suggested that the deposition of these substances as insoluble melanins served to remove them from the hemolymph and thus prevent the poisoning of the insect. This view was supported by Taylor (1969), who suggested that the quinones evolved during melanin production are oxidizing agents which are too strong to be compatible witr life. Zlotkin et al. (1973) demonstrated that melanization may in some way be poisonous to insects. They found that activated phenoloxidases from the hemolymph of tenebrionid beetles was toxic, and resulted in death, when injected into other insects. 
ADDITIONAL MATERIALS AND METHODS

Effects 요 PTU on Aedes aegypti Larvae

These experiments are described in the Materials and Methods section of the paper for publication. Three different types of experiments were conducted. The first consisted of treating larvae in PTU solutions from the time of hatch and recording mortality and dry weights on the 5th day. In the 2nd type, 4th instar larvae were placed in PTU solutions on the 4 th day and mortality and dry weights were recorded on the 5th day. The $3 r d$ type of experiment was conducted to measure the oxygen consumption of both PTU treated and untreated larvae.

Effects of PTU on Aedes aegypti Larvae Parasitized by Neoaplectana carpocapsae

These experiments are thoroughly described in the Materials and Methods section of the paper for publication. The experiments were conducted using PTU treated and untreated 5-day-old Aedes aegypti larvae which were exposed to Neoaplectana carpocapsae for $1 \mathrm{hr}$ or $9 \mathrm{hr}$.

Effects of PTU on the Distribution of Neoaplectana carpocapsae in Aedes aegypti Larvae

This set of 3 j.dentical experiments was described in the Materials and Methods section of the paper for publication. In these experiments the location of nematodes within PTU treated and untreated Aedes aegypti larvae was noted and recorded. 
Effects of Antibiotic Solutions on PTU Treated and Untreated Aedes aegypti Larvae Parasitized by Neoaplectana carpocapsae

The basic apparatus and techniques for this experiment are the same as described in other experiments using mosquito larvae and nematodes with some exceptions. The nematode concentration used in all treatments was 3000 nematodes per ml. Both PTU treated and untreated larvae were reared in various penicillin-streptomycin solutions after the 4th day. The antibiotic concentrations were $0,100,200$, and 300 units per $\mathrm{ml}$ for penicillin and $0,100,200$, and $300 \mathrm{mcg}$ per $\mathrm{ml}$ for streptomycin. The mosquito larvae were exposed to nematodes for $9 \mathrm{hr}$. 


\section{ADDITIONAL RESULTS AND DISCUSSION}

Effects of $\underline{P T U}$ on $\Lambda \in$ des aegypti Larvae

The results of experiments where mosquito larvae were reared in PTU solutions from the time of hatching are shown in Tables 4 and.5. These data show that most of the larvae reared in PTU concentrations above $0.01 \%$ died before the 5 th day. The larvae reared at $0.01 \% \mathrm{PTU}$ (Table 5) did not grow to the 4 th instar in 5 days. About $50 \%$ of these larvae were $3 r d$ instar and the other $50 \%$ were 1 st and 2nd instar. A large difference in dry weight can be seen between the larvae reared at $0.01 \% \mathrm{PTU}$ and the control larvae (Table 5).

The results of experiments conducted with 4 th instar larvae reared in various PTU solutions are shown in Tables 6 and 7 . These data indicate that larvae reared in the PTU concentrations above $0.01 \%$ show differences from the control larvae in mortality and dry weight.

The respiration experiments shown in Table 8 , demonstrated that 4th instar larvae reared in $0.01 \%$ PTU solution had a lower oxygen consumption than the untreated larvae. Except for the data seen in the top line of Table 8, the oxygen consumption of the untreated larvae corresponded with the results obtained for normal larvae by Barbosa (1971). However, nearly all the readings on the PTU treated larvae fell below the levels of oxygen consumption for normal larvae in both the present experiments and the work by Barbosa (1971).

Bodine and Fitzpatrick (1949) found that phenylthiourea solutions in excess of $0.25 \mathrm{mM}$ depressed oxygen consumption in embryos of Melanoplus differentialis. In the present study the $0.01 \%$ PTU solution 


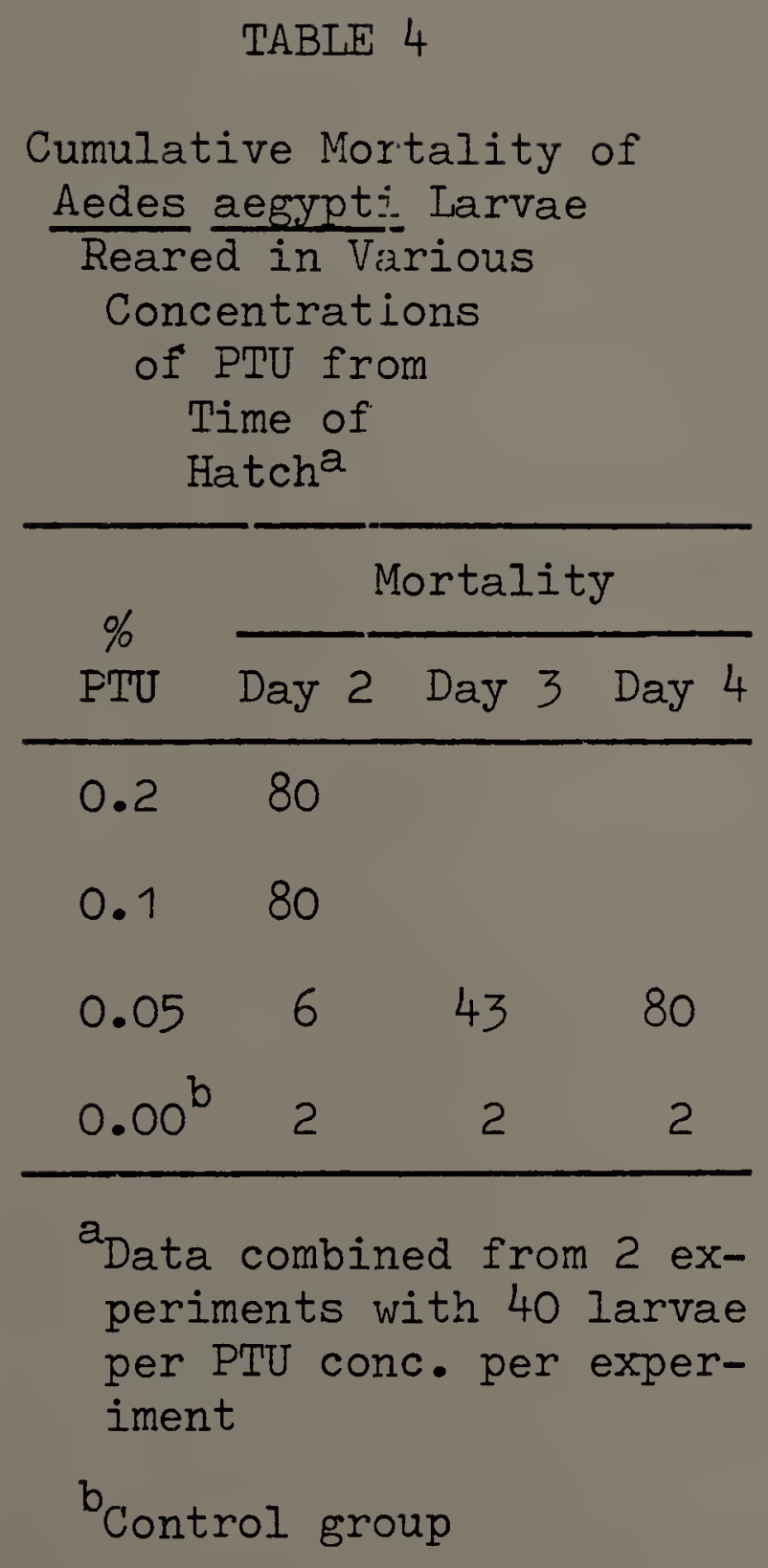


TABIE 5

Recovery and Dry Weights of 5-Day-OId Aedes aegypti

Larvae Reared in Various Concentrations of PTU

Fróm Time of Hatch

\begin{tabular}{cccc}
\hline$\%$ PTU $^{\mathrm{a}}$ & Recovery & Dry Wt. $(\mathrm{mg})^{\mathrm{c}}$ & Wt./Larvae $(\mathrm{mg})$ \\
\hline 0.05 & 0 & & \\
0.04 & 0 & & \\
0.03 & 0 & & \\
0.02 & 7 & & \\
0.01 & 34 & 0.6 & 0.0176 \\
$0.00^{\mathrm{b}}$ & 36 & 12.5 & 0.3472 \\
\hline
\end{tabular}

$a_{40}$ larvae per PTU concentration

${ }^{b}$ Control

${ }^{c}$ Of number recovered 
TABLE 6

Recovery and Dry Weights of 5-Day-0Id Aedes aegypti Larvae

Reared in Various Concentrations of PTU after the 4 th Day ${ }^{2}$

\begin{tabular}{cccc}
\hline$\%$ PTU & Recovery & Dry $W_{.}(\mathrm{mg})^{c}$ & $W t . /$ Iarvae $(\mathrm{mg})^{d}$ \\
\hline 0.05 & 90 & 26.0 & 0.289 \\
0.04 & 95 & 29.9 & 0.315 \\
0.03 & 101 & 42.6 & 0.422 \\
0.02 & 101 & 42.9 & 0.425 \\
0.01 & 114 & 53.2 & 0.467 \\
$0.00^{\mathrm{b}}$ & 112 & 52.1 & 0.465 \\
\hline
\end{tabular}

aata combined from 3 experiments with 40 larvae per PTU conc. per experiment

${ }^{b}$ Control

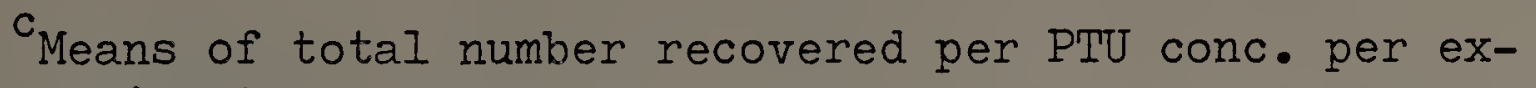
periment

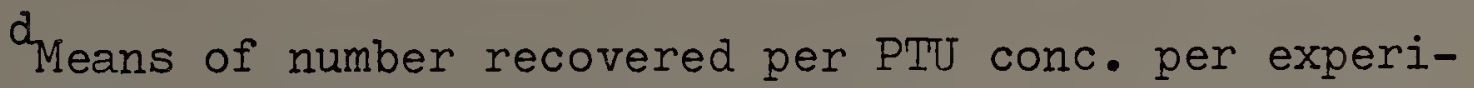
ment 


\begin{tabular}{|c|c|c|c|c|c|}
\hline \multicolumn{6}{|c|}{ TABLE 7} \\
\hline \multicolumn{6}{|c|}{$\begin{array}{c}\text { Recovery and Dry Weight per Larva of 5-Day-Old Aedes } \\
\text { aegypti Larvae Reared in Various Concentrations of } \\
\text { PTU After the } 4 \text { th Day }\end{array}$} \\
\hline Source & $d f$ & $S . S$ & M.S. & $\mathrm{F}$ & value \\
\hline \multicolumn{6}{|l|}{ Recovery } \\
\hline PTU Treatments & 5 & 146.2776 & 29.25555 & & $5.1729^{*}$ \\
\hline Repetitions & 2 & 40.1112 & 20.0556 & & 3.5462 \\
\hline Error & 10 & 56.5556 & 5.6555 & & \\
\hline \multicolumn{6}{|l|}{ Weights } \\
\hline PTU Treatments & 5 & 0.08549 & 0.01710 & & $8.8144 *$ \\
\hline Repetitions & 2 & 0.42037 & 2.10185 & & $33.4278^{*}$ \\
\hline Error & 10 & 0.01942 & 0.00194 & & \\
\hline
\end{tabular}

$* P<0.05$

**P<0.01 
TABLE 8

Oxygen Consumption ${ }^{a}$ of PTU Treated and Untreated

5-Day-01d Aedes aegypti Larvae

\begin{tabular}{llllll}
\hline & $0.01 \%$ PTU & \multicolumn{4}{c}{ Untreated } \\
\hline 5.532 & 8.579 & 10.857 & 15.176 & 11.205 \\
6.275 & 4.896 & 6.901 & 7.506 & 7.772 \\
6.890 & 6.725 & 6.714 & & 8.159 & 9.457 \\
7.207 & 6.828 & 6.327 & 7.837 & 7.488 \\
\hline
\end{tabular}

$a_{\text {in }} \mathrm{mcl} / \mathrm{mg} / \mathrm{hr}$

${ }^{b}$ Results of 4 experiments using 5 reaction vessels with 20 larvae per vessel 
is close to $0.65 \mathrm{mM}$ and therefore a decrease in oxygen consumption would be expected.

Effects of PIU on Aedes aegypti Larvae Parasitized by Neoaplectana carpocapsae

The results of the experiments using PIU treated and untreated larvae exposed to nematodes for $1 \mathrm{hr}$ were thoroughly discussed in the paper for publication. Tables 9,10 , and 11 show the analysis of variance for the data obtained.

The results of experiments using PrU treated and untreated larvae exposed to nematodes for $9 \mathrm{hr}$ are shown in Tables 12-17. These results are very similar to the results obtained for the $1 \mathrm{hr}$ exposure experiments. One difference between the $1 \mathrm{hr}$ exposure and $9 \mathrm{hr}$ exposure experiments is seen in Table 16 in the $9 \mathrm{hr}$ surviving larvae group. The number of nematodes per larvae in the PTU treated larvae is always higher than the untreated larvae, whereas in the $1 \mathrm{hr}$ exposure the number of nematodes per larva is more variable (Table 2).

Effects of PTU on the Distribution of Neoaplectana carpocapsae in Aedes aegypti Larvae

The results of these experiments are shown in Table 18 and were already discussed in the paper for publication.

Effects of Antibiotic Solutions on PTU Treated and Untreated Aedes aegypti Larvae Parasitized by Neoaplectana carpocapsae

In an attempt to assess the effect of PTU on Achromobacter nematophilus an experiment was conducted using antibiotics to suppress 
TABLE 9

Per Cent Mortality of PTU Treated and Untreated 5-Day-0Id Aecies aegypti Larvae Exposed to Various Concentrations of Neoaplectana carpocapsae for 1 Hour

\begin{tabular}{|c|c|c|c|c|}
\hline Source & $\mathrm{df}$ & S.S. & M.S. & $F$ value \\
\hline PTU Treatments ( $\mathrm{T})$ & 1 & 32.6667 & 32.6667 & $11.7599 * *$ \\
\hline Nematode Conc. (N) & 2 & 0.4444 & 0.2222 & 0.0800 \\
\hline Time $(t)$ & 2 & 58.3333 & 29.1665 & $10.4998 * *$ \\
\hline Repetitions (R) & 2 & 65.7778 & 32.8889 & $11.8399 * *$ \\
\hline $\mathbb{T N}$ & 2 & 3.1111 & 1.5555 & 0.5600 \\
\hline Tt & 2 & 14.3333 & 7.1665 & 2.5799 \\
\hline$T R$ & 2 & 3.1112 & 1.5556 & 0.5600 \\
\hline Nt & 4 & 8.8890 & 2.2222 & 0.8000 \\
\hline $\mathrm{INR}$ & 4 & 11.4446 & 2.8612 & 1.0300 \\
\hline$t R$ & 4 & $107 \cdot 5557$ & 26.8889 & $9.6799 * *$ \\
\hline Tivt & 4 & 6.2222 & 1.5556 & 0.5600 \\
\hline TNR & 4 & 3.4444 & 0.8611 & 0.3010 \\
\hline TtR & 4 & 8.8888 & 2.2222 & 0.8000 \\
\hline$N t R$ & 8 & 9.5553 & 1.1944 & 0.4300 \\
\hline TNtR (Error) & 8 & 22.2224 & 2.7778 & 4.5898 \\
\hline
\end{tabular}

$* P<0.05$

$* * \mathrm{~F}<0.01$ 
TABLE 10

Mean Nematodes Per Aedes aegypti Larva Exposed to Neoaplectana carpocapsae for 1 Hour

\begin{tabular}{|c|c|c|c|c|}
\hline Source & $\mathrm{df}$ & S.S. & $\mathrm{M} . \mathrm{S}$ & $F$ value \\
\hline PTU Treatments (T) & 1 & 9.3251 & 9.3251 & $20.3272 * *$ \\
\hline Nematode Conc. (N) & 2 & 16.4063 & 8.2032 & $17.8815^{* *}$ \\
\hline Hours $(\mathrm{H})$ & 3 & 75.3531 & $25 \cdot 1177$ & $54.7525^{* *}$ \\
\hline TN & 2 & 6.9565 & 3.4782 & $7.5820 *$ \\
\hline $\mathrm{TH}$ & 3 & 14.6217 & 4.8739 & $10.6243^{* *}$ \\
\hline $\mathrm{NH}$ & 6 & 2.7328 & 0.4555 & 0.9928 \\
\hline TNH（Error） & 6 & 2.7525 & 0.4588 & \\
\hline
\end{tabular}

$* \mathrm{P}<0.05$

**P<0.01 
TABIE 11

Per Cent Encapsulation of Neoaplectana carpocapsae by iTU Treated and Untreated 5-Day-01d Aedes aegypti Larvae Exposed to Nematodes for 1 Hour

\begin{tabular}{|c|c|c|c|c|}
\hline Source & $d f$ & $S . S$ & M.S. & $F$ value \\
\hline \multicolumn{5}{|l|}{$\%$ Encapsulation } \\
\hline PTU Treatments (T) & 1 & $1027 \cdot 3033$ & $1027 \cdot 3033$ & $12.3767^{* *}$ \\
\hline Nematode Conc. (N) & 2 & 51.8969 & $25 \cdot 9484$ & 0.3123 \\
\hline Hours $(H)$ & 3 & 4168.1479 & $1389 \cdot 3826$ & $16.7227^{* *}$ \\
\hline $\mathrm{TN}$ & 2 & 275.1418 & 137.5709 & 1.6558 \\
\hline $\mathrm{TH}$ & 3 & 1454.6792 & 484.8931 & $5.8362^{*}$ \\
\hline $\mathrm{NH}$ & 6 & 60.8943 & 10.1490 & 0.1222 \\
\hline TNH (Error) & 6 & 498.5026 & 83.0838 & \\
\hline \multicolumn{5}{|c|}{ \% Complete Capsules } \\
\hline PTU Treatments (T) & 1 & 2581.9227 & 2581.9227 & $111.8040 * *$ \\
\hline Nematode Conc. (N) & 2 & 14.6763 & 7.3381 & 0.3178 \\
\hline Hours $(\mathrm{H})$ & 3 & $8,103.6739$ & 9367.8913 & $405.6541^{* *}$ \\
\hline $\mathrm{TN}$ & 2 & 10.5712 & 5.2856 & 0.2289 \\
\hline $\mathrm{TH}$ & 3 & 939.5802 & 313.1934 & $13.5621^{* *}$ \\
\hline $\mathrm{NH}$ & 6 & 272.7564 & 45.4594 & 1.9685 \\
\hline TNH (Error) & 6 & 138.5600 & 23.0933 & \\
\hline
\end{tabular}

$* \mathrm{P}<0.05$

$* * \mathrm{P}<0.01$ 


\section{TABLE 12}

Per Cent Mortality of PTU Treated and Untreated 5-Day-Old Aedes aegypti Larvae Exposed to Various Concentrations of Neoaplectana carpocapsae for 9 Hours $^{a}$

\begin{tabular}{cccccccc} 
& \multicolumn{3}{c}{ PTU Treated } & \multicolumn{3}{c}{ Untreated } \\
\cline { 2 - 7 } $\begin{array}{c}\text { Hours } \\
\text { After } \\
\text { Exposure }\end{array}$ & \multicolumn{2}{c}{ Nematodes per m } & & \multicolumn{2}{c}{ Nematodes per ml } \\
\cline { 2 - 8 } & 4000 & 2000 & 1000 & 4000 & 2000 & 1000 \\
\hline 3 & 20.0 & 16.0 & 13.3 & 46.7 & 30.7 & 30.7 \\
6 & 33.3 & 33.3 & 32.0 & 65.3 & 53.3 & 62.7 \\
9 & 43.0 & 56.0 & 49.3 & 72.0 & 61.3 & 72.0 \\
\hline
\end{tabular}

ata combined from 3 experiments 
TABLE 13

Per Cent Mortality of PTU Treated and Untreated 5-Day-Old Aedes aegypti Larvae Exposed to Various Concentrations of Neoaplectana carpocapsae for 9 Hours

\begin{tabular}{|c|c|c|c|c|}
\hline Source & $d f$ & S.S. & M.S. & $F$ value \\
\hline PTU Treatments (T) & 1 & $25 \cdot 3518$ & 25.3518 & 4.7494 \\
\hline Nematode Conc. (N) & 2 & 0.1111 & 0.0555 & 0.0104 \\
\hline Time $(t)$ & 2 & 104.1111 & 52.0555 & 9.7521 \\
\hline Repetitions (R) & 2 & 49.0000 & 24.5000 & $4.5545 *$ \\
\hline $\mathrm{TN}$ & 2 & 6.0371 & 3.0186 & 0.5655 \\
\hline Tt & 2 & 134.9259 & 67.4630 & $12.6385^{* *}$ \\
\hline$T R$ & 2 & 2.7037 & 1.3518 & 0.2532 \\
\hline$N t$ & 4 & 49.4444 & $12 \cdot 3611$ & 2.3157 \\
\hline $\mathrm{NR}$ & 4 & 7.5555 & 1.8889 & 0.3539 \\
\hline$t R$ & 4 & $27 \cdot 5555$ & 6.8889 & 1.2906 \\
\hline TNt & 4 & 7.5186 & 1.8796 & 0.3521 \\
\hline TNR & 4 & 3.4074 & 0.8518 & 0.1595 \\
\hline $\mathrm{TtR}$ & 4 & 23.8520 & 5.9630 & 1.1171 \\
\hline $\mathrm{NtR}$ & 8 & 24.5557 & 3.0695 & 0.5750 \\
\hline TNtR (Error) & 8 & 42.7035 & 5.3379 & \\
\hline
\end{tabular}

$* P<0.05$

$* * \mathrm{P}<0.01$ 
TABLE 14

Per Cent Encapsulation of Neoaplectana carpocapsae by PTU Treated and Untreated 5-Day-01d Aedes aegypti Larvae Exposed to Nematodes for 9 Hours $^{a}$

\begin{tabular}{|c|c|c|c|c|c|c|}
\hline \multirow{3}{*}{$\begin{array}{l}\text { Hours } \\
\text { After } \\
\text { Exposure }\end{array}$} & \multicolumn{3}{|c|}{ PTU Treated } & \multicolumn{3}{|c|}{ Untreated } \\
\hline & \multicolumn{3}{|c|}{ Nematodes per ml } & \multicolumn{3}{|c|}{ Nematodes per ml } \\
\hline & 4000 & 2000 & 1000 & 4000 & 2000 & 1000 \\
\hline $3 \%$ Encapsulation & 30.58 & $1+4.44$ & 31.91 & 74.64 & 77.64 & 80.65 \\
\hline \% Complete Capsules & 0 & $4 \cdot 17$ & 6.67 & 35.44 & 44.00 & 29.60 \\
\hline $6 \%$ Encapsulation & 62.20 & 73.81 & 73.68 & 99.03 & 99.24 & 97.55 \\
\hline$\%$ Complete Capsules & 39.22 & 29.03 & 41.84 & 61.76 & 64.89 & 71.70 \\
\hline $9^{b} \%$ Encapsulation & 91.00 & 82.47 & 85.60 & 100 & 100 & 100 \\
\hline$\%$ Complete Capsules & 59.00 & 59.06 & 66.36 & 88.88 & 93.75 & 71.43 \\
\hline $9^{C} \%$ Encapsulation & 91.71 & 94.15 & 93.06 & 100 & 100 & 100 \\
\hline$\%$ Complete Capsules & 73.94 & 78.53 & 87.58 & 98.81 & 98.25 & 98.75 \\
\hline
\end{tabular}

Data combined from 3 experiments

Dead larvae

${ }^{\mathrm{c}}$ Surviving larvae 
TABLE 15

Per Cent Encapsulation of Neoaplectana carpocapsae by PTU Treated and Untreated 5-Day-01d Aedes aegypti Larvae Exposed to Nematodes for 9 Hours

\begin{tabular}{llrrr}
\hline \multicolumn{1}{c}{ Source } & df & \multicolumn{1}{c}{ S.J. } & \multicolumn{1}{c}{ M.S. } & F value \\
\hline \% Encapsulation & & & & \\
PTU Treatments (T) & 1 & 3131.3642 & 3131.3642 & $161.7607^{* *}$ \\
Nematode Conc. (N) & 2 & 32.2259 & 16.1130 & 0.8324 \\
Hours (H) & 3 & 5887.2648 & 1962.4216 & $101.3752^{* *}$ \\
TN & 2 & 17.5802 & 8.7901 & 0.4541 \\
TH & 3 & 1104.3038 & 368.1013 & $19.0155^{* *}$ \\
NH & 6 & 99.8528 & 16.6421 & 0.8597 \\
TNH (Error) & 6 & 116.1483 & 19.3580 & \\
\% Complete Capsules & & & & \\
PTU Treatments (T) & 1 & 4052.3608 & 4052.3608 & $139.4054 * *$ \\
Nematode Conc. (N) & 2 & 21.0014 & 10.5007 & 0.3612 \\
Hours (H) & 3 & $16,175.5549$ & 5391.8516 & $185.4852^{* *}$ \\
TN & 2 & 247.5397 & 123.7698 & 4.2578 \\
TH & 3 & 179.6350 & 59.8783 & 2.0599 \\
NH & 6 & 235.7430 & 39.2905 & 1.3516 \\
TNH (Error) & 6 & 174.4134 & 29.0689 & \\
\hline & & & & \\
\hline
\end{tabular}

$* P<0.05$

$* * \mathrm{P}<0.01$ 
TABLE 16

Mean Nematodes Per Aedes aegypti Larva Exposed to Neoaplectana carpocapsae for 9 Hours $^{a}$

\begin{tabular}{cccccccc}
\hline & \multicolumn{3}{c}{ PTU Treated } & \multicolumn{3}{c}{ Untreated } \\
\cline { 2 - 7 } $\begin{array}{c}\text { Hours } \\
\text { After } \\
\text { Exposure }\end{array}$ & \multicolumn{2}{c}{ Nematodes per ml } & \multicolumn{3}{c}{ Nematodes per ml } \\
\cline { 2 - 7 } & 40000 & 2000 & 1000 & 4000 & 2000 & 1000 \\
\hline 3 & 8.07 & 9.00 & 9.40 & 7.89 & 7.00 & 6.74 \\
6 & 8.20 & 9.69 & 9.50 & 7.36 & 7.76 & 6.79 \\
$9^{b}$ & 9.09 & 9.06 & 9.62 & 7.20 & 5.33 & 5.60 \\
$9^{c}$ & 5.26 & 5.70 & 4.55 & 4.00 & 3.93 & 3.48 \\
\hline
\end{tabular}

Data combined from 3 experiments

bead larvae

${ }^{c}$ Surviving larvae 
TABLE 17

Mean Nematodes Per Aedes aegypti Larva Exposed to Neoaplectana carpocapsae for 9 Hours

\begin{tabular}{lrrrc}
\hline \multicolumn{1}{c}{ Source } & df & \multicolumn{1}{c}{ S.S. } & \multicolumn{1}{c}{ M.S. } & F Value \\
\hline PTU Treatments (T) & 1 & 24.1201 & 24.1201 & $125.6473^{* *}$ \\
Nematode Conc. (N) & 2 & 0.2206 & 0.1103 & 0.5746 \\
Hours (H) & 3 & 55.3140 & 18.4380 & $96.0479^{* *}$ \\
TN & 2 & 2.8456 & 1.4228 & $7.4117^{*}$ \\
TH & 3 & 3.0792 & 1.0264 & $5.3468^{* *}$ \\
NH & 6 & 2.3057 & 0.3843 & 2.0018 \\
TNG (Error) & 6 & 1.1518 & 0.1920 & \\
\hline
\end{tabular}

$* \mathrm{P}<0.05$

$* * \mathrm{P}<0.01$ 
TABIE 18

Per Cent Distribution of Neoaplectana carpocapsae in Aedes aegypti Larvae Exposed to the Nematodes for 9 Hours $^{a}$

\begin{tabular}{lllllll}
\hline & \multicolumn{3}{c}{ PTU Treated } & \multicolumn{3}{c}{ Untreated } \\
\cline { 2 - 7 } Head & Thorax & Abdomen & Head & Thorax & Abdomen \\
\cline { 2 - 7 } Alive & 71.02 & 72.63 & 20.35 & 7.29 & 77.84 & 14.87 \\
\hline
\end{tabular}

Data combined from 3 experiments 


\section{TABLE 19}

Mortality and Nematodes per Larva of Aedes aegypti Larvae Reared in Various Penicillin-Streptomycin Solutions

\begin{tabular}{|c|c|c|c|c|c|c|c|c|}
\hline & \multicolumn{4}{|c|}{ PTU Treated } & \multicolumn{4}{|c|}{ Untreated } \\
\hline & \multicolumn{4}{|c|}{ Units per ml Antibiotic } & \multicolumn{4}{|c|}{ Units per ml Antibiotic } \\
\hline & 0 & 100 & 200 & 300 & 0 & 100 & 200 & 300 \\
\hline Mortality & 8 & 7 & 8 & 10 & 13 & 12 & 11 & 7 \\
\hline Nemas per Larva ${ }^{a}$ & $9 \cdot 12$ & $5 \cdot 57$ & 6.25 & 4.20 & 6.23 & 4.92 & 4.73 & 4.43 \\
\hline Nemas per Larva ${ }^{b}$ & 3.41 & 3.72 & 3.35 & 3.40 & 3.42 & 3.00 & 2.71 & 1.72 \\
\hline
\end{tabular}

Dead larvae

$\mathrm{b}_{\text {Surviving larvae }}$ 
growth of the bacterium. The results of this experiment are presented in Table 19. It can be seen that when 4 th instar A. aegypti larvae were reared in various penicillin-streptomycin solutions and then exposed to nematodes, the mortality of PTU treated larvae was still lower than the mortality of larvae reared without PTU present. The effects of these antibiotics on mosquito larvae, the nematodes, and the effective dosages against $\underline{A}$. nematophilus are not known. Therefore, it is difficult to draw any conclusions about this experiment. 
REPORT ON THE CULIIVATION OF AXENIC NEOAPLECTANA CARPOCAPSAE

Attempts were made to cultivate $\underline{N}$ - carpocapsae axenically on 3 different media. The axenic nematodes were to be used to determine if the early death of Aedes aegypti larvae occurred as a result of the presence of the pathogenic bacterium, Achromobacter nematophilus. The nematodes grew in all of the media, but there were never enough infective stage juveniles collected to conduct an experiment similar to the ones in the paper for publication. More information on the media and results are presented below.

In Sept. of 1973 an axenic culture of $\mathrm{N}$ - carpocapsae was obtained from Dr. E. Yarwood, of the Clinical Pharmacology Research Institute in Berkeley, California. The nematodes were grown in a liquid medium suggested to me by Dr. M. Zuckerman of the Cranberiy Experiment Station, Wareham, Mass. The medium consisted of $4 g$ soy peptone, $3 g$ yeast extract, $90 \mathrm{ml}$ water and $10 \mathrm{ml}$ of a heated calf liver extract prepared according to the method of Sayre et al. (1963). All ingredients but the heated liver extract were prepared and autoclaved in the Dept. of Entomology, Univ. of Mass. The heated liver extract was prepared in conjunction with the Dept. of Microbiology, Univ. of Mass. and added to the mediurn by filtration because it was non-autoclavable. The nematodes were reared in $10 \mathrm{ml}$ of medium in 11 brown bottles. Growth of the nematodes appeared to be slow and after two months thousands of nematodes were present in the medium. Unfortunately, only about $50 \%$ of these were infective stage juveniles. These nematodes were used as inoculum for more cultures which became contaminated and the nematodes 
died.

In March of 1974, another culture of axenic nematodes was obtained from Dr. E. C. Platzer of the Dept. of Nematology, Univ. of California, Riverside, Calif. These nematodes were cultivated on the glucosepeptone slants with pork kidney, described by Dutky et al. (1964). The nematodes grew very poorly and in transferring them to fresh medium, all cultures were lost due to contamination.

After writing back to Dr. Platzer, I was notified in August, 1974, that axenic cultures of $N$. carpocapsae were no longer available.

In the meantime $\underline{N}$ carpocapsae were taken from Galleria and glucosepeptone slants and sterilized by the technique of Poinar and Thomas (1966). The nematodes were then placed on the axenic kidney-liver medium described by Poinar and Thomas (1966). This medium was the easiest of the 3 to prepare and use. The nematodes grew well but very slowly and axenic cultures were in existence for 4 months. During this period there never were enough infective stage juveniles to conduct the planned experiments. 


\section{ADDITIONAL REFERENCES}

Ashida, M., and Ohnishi, E. 1967. Activation of prephenol oxidase in haemolymph of the silkworm, Bombyz mori. Archs. Biochem. Biophys., $122,411-416$

Babu, J. P., and Hall, J. E. 1974. Histochemical staining of melanin formed in a mayfly in response to helminth infection. J. Invertebr. Pathol., 23, 123-124.

Barbosa, P. 1971. Some effects of overcrowding on the respiration of larval Aedes aegypti. Ph.D. Thesis, University of Massachusetts. Bodine, J. H., and Fitzpatrick, L. R. 1949. Effect of urea, thiourea, phenylthiourea and thiouracil on the oxygen consumption of blocked and active embryonic cells. Biol. Bull., 96, 1-8.

Brewer, F. D., and Vinson, S. B. 1971. Chemicals affecting the encapsulation of foreign material in an insect. J. Invertebr. Pathol., $18,287-289$.

Bronskill, J. F. 1962. Encapsulation of rhabditid nematodes in mosquitoes. Can. J. Zool., 40, 1269-1275.

Chadwick, J. S. 1966. The occurrence of polyphenoloxidase in the hemocytes of actively immunized larvae of the greater wax moth, Galleria mellonella. J. Invertebr. Pathol., 8, 126-127.

Dennell, R. 1949. Weismann's ring and the control of tyrosinase activity in the larva of Calliphora erythrocephala. Proc. Roy. Soc. Lond., B., 136, 94-109.

Dutky, S. R., and Hough, W. S. 1955. Note on a parasitic nematode from codling moth larvae, Carpocausa pomonella (Lepidoptera, Olethreutidae). Proc. Entomol. Soc. Wash., 57, 244 . 
Dutky, S. R., Thompson, J. V., and Cantwell, G. E. 1964. A technique for the mass rearing of the DD-136 nematode. J. Insect Pathol., $6,417-422$

Esslinger, J. H. 1962. Behavior of microfilariae of Brugia pahangi in Anopheles quadrimaculatus. Amer. J. Trop. Med., 11, 749-758. Evans, J. J. 1967. The activation of prophenol oxidase during metabolism of the pupal blood of the Chinese oak silkworm, Antherea pernyi. J. Insect Physiol., 13, 1699-1711.

Fox, D. L. 1953. "Animal Biochromes and Structural Colors," 339 pp. Cambridge University Press, New York.

Gotz, P., and Vey, A. 1974. Humoral encapsulation in Diptera (Insecta): defence reactions of Chironomus larvae against fungi. Parasitulogy, 68, 193-205.

Lerner, A. B., and Fitzpatrick, T. B. 1950. Biochemistry of melanin formation. Physiol. Rev., 30, 91-126.

Miller, M. A. 1943. Studies on the developmental stages and glycogen metabolism of Macracanthorhynchus hirudinaceus in the Japanese beetle larva. J. Morph., 73, 19-41.

Misko, I. S. 1972. The cellular defence mechanisms of Periplaneta americana (L). Ph.D. Thesis, Australian National University. Muldrew, J. A. 1953. The natural immunity of the larch sawfly (Pristiphora erichsonii (Htg.)) to the intruduced parasite Mesolius tenthredinis Morley, in Manitoba and Saskatchewan. Can. J. Z0ol., 31, 313-332.

Nappi, A. J. 1973. The role of melanization in the immune reaction of larvae of Drosophila algonquin against Pseudeucoila bochei. 
Parasitology, 66, 23-32.

Nappi, A. J. 1974. Parasite encapsulation in insects. $48 \mathrm{pp}$. (K. Maramorosch, ed.). Academic Press, New York (In Press).

Niklas, O.F. 1967. Die nematoden DD-135 (Neoaplectana sp.) und Neoaplectana carpocapsae Weiser, 1955 (Rhabditoidea) als Insectenparasiten eine lituraturubersicht. Mitt. Biol. Bundesanst. LandForstwirt. Berlin-Dahlem., 124, 1-40.

Ohnishi, E. 1959. Studies on the mechanism of tyrosinase activation in the house fly Musca vicini Macq. J. Insect Physiol., 3, 219229.

Poinar, G. O., Jr. 1967. Description ard taxonomic position of the DD-136 nematode (Steinernematidae, Rhabditoidea) and its relationship to Neoaplectana carpocapsae Weiser. Proc. Helm. Soc. Wash., $34,199-209$.

Poinar, G. O., Jr. 1971. Use of nematodes for microbial control of insects. In: "Microbial Control of Insects and Mites" (Burges and Hussey, eds.), pp. 181-201. Academic Press, New York.

Poinar, G. O., Jr., and Leutenegger, R. 1971. Ultrastructural investigation of the melanization process in Culex pipiens (Culicidae) in response to a nematode. J. Ultrastruct. Res., 36 , $149-158$

Poinar, G. O., Jr., and Tr.onas, G. M. 1965. A new bacterium, Achromobacter nematophilus sp. nov. (Achromobacteriaceae: Eubacteriales) associated with a nematode. Int. Bull. Bacteriol. Nomen. Taxon., 15, 249-252.

Poinar, G. O., Jr., and Thomas, G. M. 1966. Significance of Achromo- 


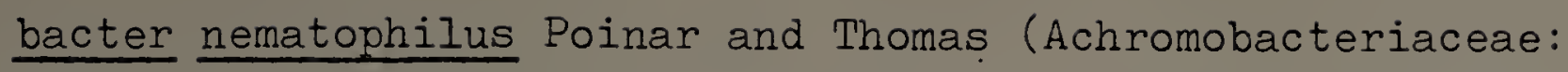

Eubacteriales) in the development of the nematode, DD-136 (Neoaplectana sp. Steinernematidae). Parasitology, 56, 385-390.

Poinar, G. O., Jr., Leutenegger, R., and Gotz, P. 1968. Ultrastructure of the formation of a melanotic capsule in Diabrotica (Coleoptera) in response to a parasitic nematode (Mermithidae). J. Ultrastruct. Res., 25, 293-306.

Poinar, G. O., Jr., Hansen, E. L., Yarwood, E. A., and Weiser, J. 1972. Clarification of the status of the DD-136 strain of Neoaplectana carpocapsae Weiser. Nematologica, 18, 288-290.

Preston, J. W., and Taylor, R. I. 1970. Observations on the phenoloxidase system in the haemolymph of the cockroach Leucophaea maderae. J. Insect Physiol., 16, 1729-1744.

Pye, A. E., and Yendol, W. G. 1972. Hemocytes containing polyphenoloxidase in Galleria larvae after infections of bacteria. J. Invertebr. Pathol., 19, 166-170.

Rizki, M. T. M., and Rizki, R. M. 1959. Functional significance of the crystal cells in the larva of Drosophila melanogaster. J. Biophys. Biochem. Cytol., 5, 235-240.

Salt, G. 1955. Experimental studies in insect parasitism. VIII. Host reactions following artificial parasitization. Proc. Roy. Soc. Lond., B., 144, 380-398.

Salt, G. 1956. Experimental studies in insect parasitism. IX. The reactions of a stick insect to an alien parasite. Proc. Roy. Soc. Lond., B. 146, 93-108. 
Salt, G. 1957. Experimental studies in insect parasitism. X. The reactions of some endopterygote insects to an alien parasite. Proc. Roy. Soc. Lond., B, 147, 167-184.

Salt, G. 1363. The defence reactions of insects to metazoan parasites. Parasitology, 53, 527-642.

Salt, G. 1970. "The Cellular Defence Reactions of Insects," 118 pp. Cambridge University Press, New York.

Sayre, F. W., Hansen, E. L., and Yarwood, E. A. 1963. Biochemical aspects of the nutrition of Caenorhabditis briggsae. Exp. Parasitol., 13, 98-107.

Stoffolano, J.G., Jr., and Streams, F. A. 1971. Host reactions of Musca dornestica, Orthellia caesarion, and Ravinia l'herminieri to the nematode Heterotylenchus autumnalis. Parasitology, 63, 195211.

Sussman, A. S. 1949. The functions of tyrosinase in insects. Quart. Rev. Biol., 24, 328-338.

Taylor, R. L. 1969. A suggested role for the polyphenol-phenoloxidase system in invertebrate immunity. J. Invertebr. Pathol., 14, 427428.

Welch, H. E., and Bronskill, J. F. 1962. Parasitism of mosquito larvae by the nematode, DD-136 (Nematoda: Neoaplectanidae). Can. J. Zool., $40,1263-1268$

Weiser, J. 1955. Neoaplectana carpocansae n. sp. (Anguillulate. Steinernematidae) novy cizopasnik housnek obalece jablecneho, Carpocapsa pomonellal. Acat. Soc. Zool. Bohemoslav., 19, 44-52. 
Whitcomb, R. F., Shapiro, M., and Granados, R. R. 1974. Insect defense mechanisms against microorganisms and parasitoids. In "The Physiology of Insecta" (M. Rockstein, ed.), Vol. 5, pp. 448537. Academic Press, New York.

Zlotkin, E., Gurevitz, M., and Shulov, A. 1973. The toxic effects of phenoloxidase from the haemolymph of tenebrionid beetles. J. Insect Physiol., '), 1057-1065. 

